Benha Veterinary Medical Journal
$\begin{gathered}\text { Official Journal Issued by } \\ \text { Factelty of } \\ \text { Veterinary Medicine }\end{gathered}$
Journal homepage: https://bvmj.journals.ekb.eg/

Original Paper

\title{
Mycological assessment of marketed duck meat in El-Qalyubia governorate markets
}

\author{
Amani M. Salem ${ }^{1}$, Marionette Z. Nassif ${ }^{2}$, Amira M. Abd-Elhalim² \\ ${ }^{I}$ Food Hygiene Department, Faculty of Veterinary Medicine, Benha University, Egypt \\ ${ }^{2}$ AnimalHealth Research Institute (Benha branch), Egypt
}

\begin{tabular}{|c|c|}
\hline ARTICLE INFO & ABSTRACT \\
\hline & This study was conducted to evaluate the mycological contamination of duck carcasses, and its \\
\hline Aflatoxin & hazards on public health. A total of two hundred meat samples of duck meat were taken from \\
\hline Duck & chilled and frozen breast and thigh ( 100 of each) that were collected from supermarkets in El- \\
\hline Fungi & Qalyubia governorate for mycological examination. The mean values of yeast and mold count \\
\hline Mold & breast and thigh, respectively. Also, those frozen samples had mean values of $3.0 \times 10^{2} \pm 0.3 \times 10$ \\
\hline Mycotoxin & $\mathrm{cfu} / \mathrm{g}$ and $6.0 \times 10^{2} \pm 0.4 \times 10 \mathrm{cfu} / \mathrm{g}$ for breast and thigh, respectively. PCR amplification was \\
\hline Received06/10/2019 & $\begin{array}{l}\text { resulted in three toxigenic strains of } A \text {. flavus, A. fumigatus and A. niger were isolated from } \\
\text { examined samples. Aflatoxin residues were detected in breast and thigh of } 0.26 \text { and } 0.33 \mathrm{ng} / \mathrm{g} \text {. }\end{array}$ \\
\hline $\begin{array}{l}\text { Accepted } 03 / 11 / 2019 \\
\text { Availa6le On-Line } \\
12 / 05 / 2020\end{array}$ & $\begin{array}{l}\text { Thus, strict hygienic precautions during processing of duck products should be adopted to } \\
\text { reduce mold contamination and mycotoxin production. }\end{array}$ \\
\hline
\end{tabular}

\section{INTRODUCTION}

Due to the high need of the world to animal protein which is considered the most important element than other food elements at all, because it contributes in all building processes which are responsible for repairing of the damaged body tissues. So, the world as a whole begins to increase poultry production, processing and utilization. Duck is still very popular and in strong demand in many area of the world, especially in Asia. In addition, Duck and geese production accounts for about $7.5 \%$ of the total world poultry meat production (Pigel, 2004).

Duck meat considered a good source of protein for humans(Adzitey et al., 2012a) and is high in iron, selenium, and niacin, as well as containing fewer calories than many cuts of beef (Adzitey et al., 2012b).

Mold and yeast comprise a large group of microorganisms which are ubiquitous in nature due to easy dissemination and their vegetative spores, which are produced in large numbers and can present in the environment for a long period. Contamination of duck meat with fungi starts in the environment of the slaughter halls due to a lack of hygienic measures through air, wall, floor, utensils, feather and intestinal contents of the slaughtered birds (Mansour, 1986).Contaminated feed is a main source for mold and mycotoxin infection of farm animal (Sayedetal., 2000). A long with molds, yeasts belong to the class mycotaor fungi, they are microscopic, single-celled organisms generally larger than the bacteria.
Fungi are not only major spoilage agents of meat results in a reduction of quality with significant economic losses but also cause contamination of meat with secondary metabolites called mycotoxins.

The most well-known among the mycotoxins are aflatoxins (AFs), which are a group of heterocyclic metabolites produced by the fungi of the genus AspergillusThe four naturally occurring AFs: aflatoxins B1, B2, G1 and G2, are toxic, mutagenic and carcinogenic compounds (CAST, 2003), and having teratogenic, hepatotoxic, mutagenic and teratogenic effects(Kensleretal.,2011). A potential immunosuppressant and nutritional interference effect has also been reported (Williams et al., 2004).

Thus, this study was designed to investigate the mycological state marketed duck meat in El-Qalyubia governorate markets.

\section{MATERIAL AND METHODS}

\subsection{Collection of samples:}

Two hundred random samples of chilled and frozen duck meat with skin (breast and thigh (fifty of each) were collected from different localities in Benha city in ElQalyubia governorate markets, Egypt in winter season. Samples were identified, packed and transferred to the laboratory in icebox under complete aseptic conditions without undue delay and subjected to the mycological examination.

\footnotetext{
* Corresponding author: Amira M. Abd-Elhalim. Animal Health Research Institute (Benha branch), Egypt
} 
2.2. Preparation of samples (APHA, 2001) and investigation Twenty-five grams of examined duck meat samples were aseptically excised and homogenized in $225 \mathrm{ml}$ of sterile buffered peptone water $0.1 \%$ at $2000 \mathrm{rpm}$ for $1-2$ min using a sterile homogenizer. Such homogenate represents the dilution of 10-1, and then decimal dilutions were done. Then prepared samples subjected to the following examination: 2.2.1. Mold and yeast count (Bailey and Scott, 1998)

2.2.2. Isolation and identification of isolated mold and yeast based on their micromorphological properties (Pitt and Hocking 2009)

2.2.3.Identification of toxigenic mold strains by using $P C R$ 2. 2.4. Determination of aflatoxin residues by $L C-M S / M S$

\section{RESULTS}

It is evident from the result recorded in table (1) that the mean value of yeast and mold counts (cfu/g) in the examined chilled duck meat were $3.1 \times 10^{2} \pm 0.02 \times 10^{2}$ and $5.5 \times 10^{2} \pm 0.4 \times 10^{2}$ and also, in frozen ones were $3.0 \times 10^{2} \pm 0.3 \times 10^{2}$ and $6.0 \times 10^{2} \pm 0.4 \times 10^{2}$ in breast and thigh samples, respectively. In comparing chilled and frozen samples, no difference was found neither between the breast samples nor the thigh samples. While, a significant $(\mathrm{p} \leq 0.05)$ difference has been found between breast and thigh samples Moreover, results in table (2) revealed that the percentage of accepted samples for mold and yeast count were $80 \%, 72 \%$, $36 \%$ and $24 \%$ in chilled and frozen breast and thigh, respectively, according to maximum permissible limits stipulated by EOS(2005).

Table 1 Statistical analytical results of mold and yeast count (cfu/g) in the examined chilled and frozen duck meat samples $(n=100)$.

\begin{tabular}{lcccc}
\hline Duck meat samples & & Min. & Max. & Mean \pm S.E.* \\
\hline Chilled & Breast & $5.0 \times 10$ & $7.3 \times 10^{2}$ & $3.1 \times 10^{2} \pm 0.2 \times 10^{2 \mathrm{~b}}$ \\
& Thigh & $8.0 \times 10$ & $1.1 \times 10^{3}$ & $5.5 \times 10^{2} \pm 0.4 \times 10^{2 \mathrm{a}}$ \\
Frozen & Breast & $1.0 \times 10$ & $1.0 \times 10^{3}$ & $3.0 \times 10^{2} \pm 0.3 \times 10^{2 \mathrm{~b}}$ \\
& Thigh & $7.0 \times 10$ & $1.1 \times 10^{3}$ & $6.0 \times 10^{2} \pm 0.4 \times 10^{2 \mathrm{a}}$
\end{tabular}

*S. E. $=$ Standard Error of Mean. ${ }^{\text {ab }}$ values within a column with different superscript letters were significantly different at $(\mathrm{P} \leq 0.05)$.

Table 2 Acceptability of the examined duck meat samples based on their mold and yeast count $/ \mathrm{g}(\mathrm{n}=50)$

\begin{tabular}{|c|c|c|c|c|c|}
\hline \multirow{2}{*}{$\begin{array}{l}\text { Duck meat } \\
\text { sample }\end{array}$} & \multirow[t]{2}{*}{$* \mathrm{PL}$} & \multicolumn{2}{|l|}{$+\mathrm{ve}$} & \multicolumn{2}{|c|}{ Accepted sample } \\
\hline & & No & $\%$ & No & $\%$ \\
\hline Chilled breast & & 10 & 20 & 40 & 80 \\
\hline Chilled thigh & & 14 & 28 & 36 & 72 \\
\hline Frozen breast & & 32 & 64 & 18 & 36 \\
\hline Frozen thigh & & 38 & 76 & 12 & 24 \\
\hline
\end{tabular}

*PL: Permissible limit according to Egyptian Organization for Standardization "EOS" (1651/2005) for chilled duck meat and EOS (1090/ 2005) for frozen duck meat.

Result in table (3) showed that incidence of mold genera isolated from examined duck meat samples of chilled and frozen samples (in breast and thigh) were Aspergillus ochraceous $2 \%, 4 \%, 8 \%, 0 \%$ and, Aspergillus niger $4 \%, 6 \%$, $12 \% 16 \%$ and Aspergillus fumigatus $4 \%, 2 \%, 0 \% 10 \%$ and Aspergillus flavus $4 \%, 6 \%, 6 \%, 2 \%$ and penicillium camberti $0 \%, 4 \%, 8 \%, 6 \%$ and penicilliumpaxilli4\%, $0 \%$, $6 \%, 2 \%$ and Mucor spp. 2\%, 0\%, 10\%, 6\% andAlternaria $0 \%, 4 \%, 8 \%, 14 \%$ and Rhizopusspp. 0\%, $2 \%, 6 \%, 10 \%$.

It is evident from the results recorded in table (4) that incidence of yeast genera isolated from examined duck meat samples of chilled and frozen samples (in breast and thigh) ,respectively were Saccharomyces spp $6 \%, 14 \%, 0 \%, 4 \%$ and Candida tropicalis $2 \%, 12 \%, 4 \%, 2 \%$ and Candida albicans $5 \%, 16 \%, 6 \%$ 4\% and Rhodotorularubra $2 \%, 8 \%$, $2 \% \quad 2 \%$ and Rhodotorula Minuta 10\%, 14\%, 0\% 6\% and Rhodotorula mucilaginosa $4 \%, 18 \%, 10 \%, 16 \%$.

Table 3 Incidence of isolated mold genera from examined chilled and frozen breast and thigh duck meat samples $(\mathrm{n}=50)$.

\begin{tabular}{lcccccccc}
\hline \multirow{2}{*}{ Isolates } & \multicolumn{3}{c}{ No. of positive samples } & \multicolumn{3}{c}{$\%$} \\
\cline { 2 - 10 } & \multicolumn{2}{c}{ Chilled } & \multicolumn{2}{c}{ Frozen } & \multicolumn{2}{c}{ Chilled } & \multicolumn{2}{c}{ Frozen } \\
\cline { 2 - 10 } & B & Th. & B & Th. & B & Th. & B & Th. \\
\hline A. ocharceus & 1 & 2 & 4 & - & $2 \%$ & $4 \%$ & $8 \%$ & - \\
\hline A. niger & 2 & 3 & 6 & 8 & $4 \%$ & $6 \%$ & $12 \%$ & $16 \%$ \\
\hline A. fumigatus & 2 & 1 & - & 5 & $4 \%$ & $2 \%$ & - & $10 \%$ \\
\hline A. flavus & 2 & 3 & 3 & 1 & $4 \%$ & $6 \%$ & $6 \%$ & $2 \%$ \\
\hline $\begin{array}{l}\text { Penicillium } \\
\text { camberti }\end{array}$ & - & 2 & 4 & 3 & - & $4 \%$ & $8 \%$ & $6 \%$ \\
\hline Penicillium paxilli & 2 & - & 3 & 6 & $4 \%$ & - & $6 \%$ & $12 \%$ \\
\hline Mucor spp. & 1 & - & 5 & 3 & $2 \%$ & - & $10 \%$ & $6 \%$ \\
\hline Altrnaria & - & 2 & 4 & 7 & - & $4 \%$ & $8 \%$ & $14 \%$ \\
\hline Rhizopus spp. & - & 1 & 3 & 5 & - & $2 \%$ & $6 \%$ & $10 \%$ \\
\hline Total & 10 & 14 & 32 & 38 & $20 \%$ & $28 \%$ & $64 \%$ & $76 \%$ \\
\hline B: Breast. Th.: Thigh. A.: Aspergillus. & & & & & &
\end{tabular}

Table 4 Incidence of isolated yeast genera from examined chilled and frozen duck meat samples $(\mathrm{n}=50)$

\begin{tabular}{|c|c|c|c|c|c|c|c|c|}
\hline \multirow{3}{*}{ Isolates } & \multicolumn{4}{|c|}{ No. of positive samples } & \multicolumn{4}{|l|}{$\%$} \\
\hline & \multicolumn{2}{|c|}{ Chilled } & \multicolumn{2}{|c|}{ Frozen } & \multicolumn{2}{|c|}{ Chilled } & \multicolumn{2}{|c|}{ Frozen } \\
\hline & $\mathrm{B}$ & Th & B & Th & B & Th & B & Th \\
\hline Saccharomyces spp. & 3 & 7 & - & 2 & $6 \%$ & $14 \%$ & - & $4 \%$ \\
\hline Candida tropicalis & 1 & 6 & 2 & 1 & $2 \%$ & $12 \%$ & $4 \%$ & $2 \%$ \\
\hline Candida albicans & 6 & 8 & 3 & 2 & $5 \%$ & $16 \%$ & $6 \%$ & $4 \%$ \\
\hline R. rubra & 3 & 4 & 1 & 1 & $2 \%$ & $8 \%$ & $2 \%$ & $2 \%$ \\
\hline R. minuta & 5 & 7 & - & 3 & $10 \%$ & $14 \%$ & - & $6 \%$ \\
\hline R. mucilginosa & 2 & 9 & 5 & 8 & $4 \%$ & $18 \%$ & $10 \%$ & $16 \%$ \\
\hline Total & 22 & 41 & 11 & 17 & 44 & 82 & 22 & 34 \\
\hline
\end{tabular}

B: Breast. Th.: Thigh. R: Rhodotorula

Fig. 1 showed that there were three toxigenic strains out of 4 chosen samples. On the other hand, results in table (5) revealed that incidence of toxigenic strains of Aspergillus spp. isolated from examined chilled and frozen duck meat samples were Aspergillusflavus $2 \%, 0 \%, 0 \%, 0 \%$ and Aspergillus fumigatus 0\%, 0\%, 0\%, 2\% and Aspergillus niger $0 \%, 0 \%, 0 \%, 2 \%$ in breast and thigh ones.

Result in table 6showed,aflatoxin residues in examined duck samples were $0.26 \mathrm{ng} / \mathrm{g}$ in chilled and $0.33 \mathrm{ng} / \mathrm{g}$ in frozen breast but were not detected in frozen thigh samples.

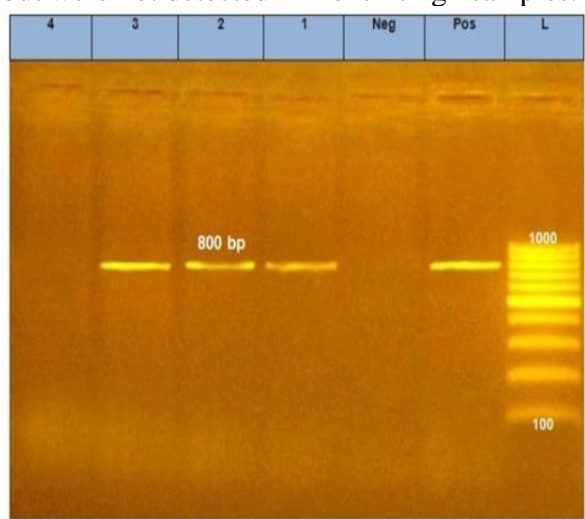

Fig. 1 Result of PCR amplifications. Lane L: 100-1000 bp DNA Ladder. Neg.: Negative control. Pos.: Positive control (at 800 bp). Lan 1-3: Toxigenic strain positive samples 
Table 5 Incidence of toxigenic strains of Aspergillus spp. isolated from examined chilled and frozen duck meat samples $(\mathrm{n}=50)$.

\begin{tabular}{lllllllllll} 
Isolates & \multicolumn{8}{c}{ Positive samples } \\
& \multicolumn{3}{c}{ Breast } & \multicolumn{2}{c}{ Thigh } & \multicolumn{2}{c}{ Breast } & \multicolumn{2}{c}{ Thigh } \\
& No & $\%$ & No & $\%$ & No & $\%$ & No & $\%$ \\
\hline A. flavus & 1 & $2 \%$ & - & & - & - & - & - & - \\
A. fumigatus & - & - & - & - & - & - & 1 & $2 \%$ \\
\hline A. niger & - & - & - & - & - & - & 1 & $2 \%$
\end{tabular}

Table 6 Aflatoxins residue in the examined duck meat samples $(n=50)$.

\begin{tabular}{|c|c|c|c|c|c|}
\hline \multicolumn{2}{|c|}{$\begin{array}{l}\text { Duck meat } \\
\text { samples }\end{array}$} & \multirow{2}{*}{$\begin{array}{c}\begin{array}{c}\text { No. of } \\
\text { positive } \\
\text { samples }\end{array} \\
1\end{array}$} & \multirow{2}{*}{$\begin{array}{c}\begin{array}{c}\text { Toxigenic } \\
\text { isolated strains }\end{array} \\
\text { A. flavus }\end{array}$} & $* \mathrm{PL}$ & $\begin{array}{c}\text { Amount of } \\
\text { aflatoxin } \\
\text { (ng/g) }\end{array}$ \\
\hline \multirow[t]{2}{*}{ Chilled } & Breast & & & \multirow{2}{*}{ free } & 0.26 \\
\hline & thigh & - & - & & - \\
\hline \multirow[t]{2}{*}{ Frozen } & Breast & 1 & A. niger & \multirow{2}{*}{ free } & 0.33 \\
\hline & Thigh & 1 & A. fumigatus & & 0 \\
\hline
\end{tabular}

*PL $=$ permissible limit according Egyptian Organization for Standardization "EOS (1651/2005) for chilled duck meat and EOS (1090/2005) for frozen duck meat

\section{DISCUSSION}

Molds are widely distributed in nature, both in the soil and in the dust carried by air. They may contaminate poultry meat at any stage of the production process and may render the product of inferior quality or even unfit for consumption, thus resulting in economic losses.

The result presented in table (1)revealed that yeast and mold count were higher in thigh samples than breast. Also, in chilled and frozen. This may be attributed to higher contamination from the ground and fecal matter. High counts may be due to unsanitary condition during preparation procedures, prolonged frozen storage period, contamination before and/or after slaughtering, bad handling during retail display and bad storage conditions or exposure to condition favoring mold proliferation and contamination of meat from different sources as skin of animals, pollution in abattoir atmosphere, visceral content in normal condition, transport and storage, halving, quartering, packaging utensil and also the water used for cleaning and personal uses (Thatcher and Clark, 1978).

According to our results, nearly similar results were obtained by Odetunde et al. $(2011)\left(1.3 \times 10^{1}\right.$ to $1.5 \times 10^{2} \mathrm{cfu} / \mathrm{g}$ inchilled chicken meat), Ogu et al. (2017)(1.3-4.0× $10^{2} \mathrm{cfu} / \mathrm{g}$ in frozen chicken meat) and Nossair et al. (2015) (1×10 to $9.1 \times 10^{3}$ with a mean value $3 \times 10^{2} \pm 1.2 \times 10$ in frozen chicken). While higher results recorded by Hassan (2014) $\left(7.57 \times 10^{2} \pm 1.06 \times 10^{2}\right.$ and $1.12 \times 10^{3} \pm 0.28 \times 10^{3} \mathrm{cfu} / \mathrm{g}$ in duck breast and thigh), Omorodion Nnenna $(2016)\left(2.7 \times 10^{4}\right.$ $5.9 \times 10^{5} \mathrm{cfu} / \mathrm{g}$ in frozen chicken meat).But, lower results obtained by Capita et al. (2001)(2.99log $10 \mathrm{cfu} / \mathrm{g}$ refrigerated chicken carcasses).These results disagree with Almorshidy (2013), who found that raw poultry samples were free of fungi and Darwish et al. (2016)(breast had the highest mold count than thigh).

Moreover, results in table (2) revealed that, the acceptable samples of frozen samples were lower than that of chilled ones. This may be due to intermittent freezing, temperature fluctuations in a storage works or improper ventilation which are common predisposing causes to mold growth.

Results achieved in table (3) illustrated that Aspergilluswere the highest mold species isolated in both chilled and frozen samples, followed by Penicillium, Mucor, Alternaria, Rhizopous spp. They revealed that Aspergillus spp. isolated from examined duck meat were A. niger which was identified in high percentage in frozen samples. While, $A$. flavus, A. fumigatus and A. ocharceus were nearly equally isolated in fresh and frozen samples. This declared that freezing did not destroy Aspergillus. These results agreed with El-kewaiey (2014)(A. flavus and A. niger), Pencillum, Fusarium, Mucor were the most common fungi isolated from frozen duck meat, Rahal (2013), who said that highest recorded were Aspergillus 44(37\%), followed by Penicilliumin chicken meat.Darwish et al. (2016) (The prevalent mold genera were Aspergillus, Penicillium, Cladosporiumand alternaria. Aspergillus niger, flavus, parasiticus and versicolorwere the identified Aspergilli In frozen chicken). But they werein a difference with those obtained by Abdel-Rahman et al.(1985) (Penicillium, Caldosporium, Aspergillus,Mucor, Geotrichum, Thamnidium, Rhizopus, Paecilomyces, Scopulariopsis and Botrytiswere isolated from frozen poultry meat).

Moreover, results in table (4) illustrated that Rhodotorula was the highest yeast species in both chilled and frozen samples, followed by Candida and Saccharomyces spp. Isolated Rhodotorulaspp.WereRhodotorulamucilginosa which were identified in high percentage in frozen samples and Rhodotorulaminuta and Rhodotorularubra were higher in chilled samples. This may be due the different effect of cooling temperature in yeast genera .The previous result agreed with Hussein (1995) (the isolated yeast species were Candida, Torulopsis, Rhodotorula, Saccharomyces and Trichosporon pullulans with varying total percentagesfrom frozen poultry)and Shawish (2011) who isolated candida spp., rhodotorula spp., saccharomyces spp., torulopsis spp. from chicken cuts.But different results obtained by (AbdelRahman and Yassien, 1995)(isolated yeast genera were Debaryomyces, Saccharomyces, Rhodotorula, Torulopsis, Endomyces, Trichosporon, Cryptococcus, Candida and Pichia, respectively in frozen meat) and Rahal (2013), who isolated Candida as the highest total incidence followed by Rhodotorula and the lowest total incidence was Saccharomyces

Fig (1) showed that aflatoxin was found in 3 out of $4(75 \%)$ samples. This result disagreed with Iqbal et al. (2014), who found that $35 \%$ of examined chicken samples contain aflatoxin, and El-kewaiey (2014)(10\% of duck samples were positive to aflatoxins).

As shown in results in table (5) the incidence of toxigenic strains of Aspergillus spp. in frozen samples were high than in chilled ones. This declared that Aspergillus strains were not affected by low temperature and can grow well.

Result in table (6) showed that aflatoxin residues were higher in frozen duck samples than chilled ones. Moreover, breasts were higher than thigh samples which were free. This result was lower than Mohamed (2004) $(8.10+0.71$ $\mathrm{ug} / \mathrm{kg})($ Pitt, 1984) reported that the total viable counts of molds are not a reliable indicator of mycotoxin production.

\section{CONCULOSION}

Finally, the present study concluded that duck carcasses can contribute to mycological risk and contamination. Consequently, frozen samples were more contaminated with fungi, the toxigenic strains and also aflatoxin residues were higher in frozen samples than chilled ones. Strict maintenance of good practices of hygiene, strengthened by 
maintaining the cold chain is of central importance to ensure both public health protection and meat quality of ducks.

\section{REFERENCES}

1. Abdel-Rahman,H.,Darwish, A.,Hamdy, M.1985.Mold affection of a meat cold store. Assuit Vet. Med. J., 14 (27):131-134

2. Abdel-Rahman, H.A.,Yassien, M.A.1995.Psychotrophic fungi in imported consignments of frozen meats.Benha Vet. Med. J., 6(1): 29- 42

3. Adzitey, F., Rusul, G., and Huda, N. 2012a. Prevalence and antibiotic resistance of Salmonella serovars in ducks, duck rearing and processing environments in Penang, Malaysia. Food Res. Int. 45, 947-952.

4. Adzitey, F., Huda, N., Rusul, G. 2012b. Prevalence and antibiotic resistance of Campylobacter, Salmonella, and L. monocytogenes in ducks: A Review. Foodborne Pathog. Dis. 9, 498-505

5. Almorshidy, O.E. 2013.aflatoxin content of raw and processed poultry meat products sold in Alexandria markets. M. thesis fac. Vet. Med., Alex Univ.

6. American Public Health Association (APHA) 2001 Compendium of methods for the microbiological examination of food, $4^{\text {th }}$ Ed. Washington, D.C.

7. Bailey, W.R, Scott. E.G.1998. Diagnostic microbiology textbook for isolation and identification of pathogenic organisms. The C.V Mosby Company SarntHouis.

8. Bintvihok, A., Treebonmuang, S., Srisakwattana, K.; Nuanchun, W.; Patthanachai, K. and Usawang, S. 2016.A Rapid and sensitive detection of aflatoxin-producing fungus using an optimized polymerase chain reaction (PCR). Toxicol Res.;32(1):81-87.

9. Capita, R., Alonso-Calleja, C., Garcia-Fernandez, M. D. and Moreno, B. 2001.Microbiological quality of retail poultry carcasses in Spain. J Food Prot.;64(12):1961-1966.

10. CAST 2003.Council for Agricultural Science and Technology. Mycotoxins. Risks in plant, animal, and human systems. Ames, Iowa. (Task Force Report 139).

11. Darwish1, W.S., El Bayomi, R.M., Abd El-Moaty, A.M., Gad, T.M. 2016. Mould contamination and aflatoxin residues in frozen chicken meat-cuts and giblets. Japanese J. of Vet. Res. 64(Supplement 2): S167-171.

12. Egyptian Organization for Standardization and Quality (EOS: 4178 / 2005

13. El-Kewaiey, A.A. 2014.Mycological quality and aflatoxin residues in some poultry meat in Damanhour city.Assiut Vet.Med. J. 60 (140): 191-199

14. Hassan, R. N. A. 2014. Microbial quality of cut-up frozen duck meat. M. Thesis. Fac., Vet. Med., Benha Univ.

15. Hussein,E.M.H. 1995.Mycological studies on poultry and poultry meat products marketed at Sharkia with special reference to toxogenic strains. M. V. Sc. Thesis, Fac. Vet. Med. Zagazig Univ., Egypt.

16. Iqbal, S.Z., Muhammad, S.N.,Asi, R. and Jinap, S 2014. Natural incidence of aflatoxins, ochratoxin A and zearalenone in chicken meat and eggs.Food Control , 43, 98 103.

17. Kensler, T.W., Roebuck, B.D., Wogan, G.N., Groopman, J.D 2011.Aflatoxin: a 50-year odyssey of mechanistic and translational toxicology. Toxicological Sciences, 120 (S1): S28-S48.

18. Mansour, N.K.M. 1986.ZumVorkommen von Schimmelpilzen der Gattung Cladosporium link Ex Fries auf Schaffleisch. Ph.D Thesis, Munchen, Germany.

19. Nossair, M.A., El Shabasy, N.A., Hassan, O.S., Samaha, I. A. 2015.Microbiological Status of Poultry Carcasses from Retailed Outlets in Alexandria Province.Alexandria. J. Vet. Sci, 46(1): 66-73.

20. Odetunde, S.K., Lawal, A.k., Akolade, M.A., Bakry, S.B. 2011. Microbial flora of frozen chicken part varieties. Int. Res. J. Microbiol. 2(11): 423-427.

21. Ogu, G.I., Madar, I.H., Igborgbor, J.C., Okolo, J.C. 2017. Mycological Quality of Fresh and Frozen Chicken Meat Retailed within Warri Metropolis, Delta State, Nigeria. Jordan J.Biolo.Sci. 10 (4): 303-308.

22. OmorodionNnennaJp. 2016. Microbial profile of chicken meat sold at different locations in port harcourt metropolis. Rep. Opinion (8)5. 44-49.

23. Pingel, H. 2004. Duck and geese production around the world poultry magazine. $8(20): 26-28$

24. Pitt, J.I. 1984. The significance of potentially toxigenic fung in food. Food Technol. in Australia, 36 (5): 218-219.

25. Pitt, J.I., Hocking, A.D. 2009.Fungi and Food spoilage.3rd ed Springer Science + Business Media, LLC, 233 Spring Street, New York, NY 10013, USA

26. Rahal, E. 2013. Mycological studies on chicken meat and their products.M. V. Sc. Thesis Fac. Vet. Med., Suez Canal Univ., Egypt

27. Sambrook, J., Fritscgh, E.F.,Mentiates, 1989.Molecula cloning. A laboratory manual.Vol 2., Cold spring Harbor Laboratory press, New York.

28. Sayed, M.A., Mohamoud, E.L.A., Abou-EIAlIa, A.A. 2000 Mycoflora and natural occurrence of mycotoxins in meat and livers of imported bulls, poultry and some meat products, Assuit Vet. Med. J., 43, 188-200.

29. Shawish, R.R.M. 2011. Microbial evaluation of some retailed cut-up chicken and poultry meat products. M.Sc. thesis, Meat Hygiene, Sadat branch Minofyia Univ.

30. Thatcher, F.S., Clark, D.S. 1978. Coliform bacteria, Pp 128 129. In Thatcher, F.S., Clark, D.S. (eds.), Microorganisms in foods, their significance and methods of enumeration.Vo. 1 , $2^{\text {nd }}$ ed. Univ. Tornato. Press, Tornato.

31. Williams, J. H., Phillips, T. D., Jolly, P. E., Stiles, J. K., Jolly, C. M., Aggarwal, D.2004. Human aflatoxicosis in developing countries: A review of toxicology, exposure, potential health consequences, and interventions. Am. J. Clin. Nutr.80(5):1106-1122. 